\title{
Advance Praise for Globalizing L.A.
}

Strictly by itself, and on its own terms, metropolitan Los Angeles is a city-state, a world force, the de facto capital of the Asia/Pacific community. In this compelling, exhaustively researched study, Steven P. Erie offers a preeminent example of how global and local energies are converging to create a new kind of global city and a new kind of global economy.

\section{-Kevin Starr, State Librarian of California}

Steven Erie provides a distinctive and persuasive analysis of political strategies that have been central to shaping the growth of the complex Los Angeles region. The book should be of much interest to scholars who are concerned with the development of the L.A. region and the role of semi-autonomous governments in the United States and beyond.

\section{- Jameson Doig, professor of politics and public affairs, Princeton University}

Although there have been several books about the area [L.A.], largely by geographers of the L.A. School, none has captured the interaction of politics and economic interest in the context of key infrastructure investments as Steve Erie is able to do. His combination of mastery of political, financial, and technical elements of development is outstanding. It will be an important contribution to our understanding of regional development.

-Michael B. Teitz, program director, economy, and senior fellow, Public Policy Institute of California and emeritus professor, University of California, Berkeley

A significant new contribution to the study of urban development. . . This book will change the way we think about Los Angeles and Southern California. . . . It is the next great book on the region.

-David Perry, director, Great Cities Institute, University of Illinois at Chicago

This is the first major study of L.A.'s trade infrastructure and goes far beyond earlier books on L.A. It will add significantly to the existing literature on urbanization, the impact of globalization on local communities, the emergence of economic regions or city-states, and the history of the Los Angeles region itself.

-Earl Fry, professor of political science, Brigham Young University

Globalizing L.A. is a major achievement. I know of nothing in the existing literature on urban politics, regional policy studies, regime theory, or developmental policy that is of comparable quality. This book makes major contributions to the existing literature in political science, and equally to new schools of thought surfacing in economic geography, sociology, and urban planning.

—David J. Olson, professor of political science, Harry Bridges Chair Emeritus, University of Washington 


\section{Globalizing L.A.}

Trade, Infrastructure, and Regional Development

Steven P. Erie

STANFORD UNIVERSITY PRESS

S T A N F OR D, C A L I F O R N I A

$2 \circ \circ 4$ 
Stanford University Press

Stanford, California

(C) 2004 by the Board of Trustees of the Leland Stanford Junior University.

All rights reserved.

Printed in the United States of America on acid-free, archival-quality paper

\section{Library of Congress Cataloging-in-Publication Data}

Erie, Steven P.

Globalizing L.A. : Trade, infrastructure, and regional development / Steven P. Erie.

p. $\quad \mathrm{cm}$.

Includes bibliographical references and index.

ISBN 0-8047-4680-X (alk. paper)-ISBN 0-8047-4681-8 (pbk. : alk. paper)

1. Los Angeles (Calif.)-Commerce-History. 2. Los Angeles (Calif.)-Economic policy. 3. Regional planning-California-Los Angeles. I. Title.

HF3163.L7 E75 2004

$382^{\prime} .09794^{\prime} 94-\mathrm{dc} 22$

2003022782

Typeset by G\&S Typesetters in Sabon 9.7/11.5

Original Printing 2004

Last figure below indicates year of this printing:

$\begin{array}{llllllllll}13 & 12 & 11 & 10 & 09 & 08 & 07 & 06 & 05 & 04\end{array}$ 